\title{
Rank of Incorporated Human Rights Treaty in the Domestic Legal System of Ethiopia
}

\author{
Dereje Alemu Goftuma \\ School of Law, Wolaita Sodo University, P.O. Box 138, Wolaita Sodo, Ethiopia
}

\begin{abstract}
The interplay between domestic and international law depicts a structural dependence of the latter on the former for its domestic implementation. International law recognizes a state to determine manner and means of incorporating international treaties into domestic laws. On the other hand when it comes to the substantive relationship between international law and domestic law the rules of international law dictate the hierarchically higher status of the international norm. Contrary to such facts, the emergent consensus of the dominant literature on the rank of human rights treaties in Ethiopia follows the mistaken approach which allows domestic law to determine the position of treaties at the national level. This article aims to rebut such mistaken approach by presenting three evidences from international law which prove the hierarchically higher status of ratified human rights treaties within the Ethiopian domestic legal system: the nature of obligation imposed by human rights treaties, the principle of pacta sunt servanda, and the principle of consistent interpretation. The author concludes that ratified human rights treaties occupy a position superior to that of Ethiopian constitution and other laws, which, if inconsistent with ratified treaties, should give way to the domestic application of treaty-provisions.
\end{abstract}

Keywords: International law, domestic law, rank, incorporation, human rights, treaties

DOI: $10.7176 / \mathrm{DCS} / 11-1-04$

Publication date: January $31^{\text {st }} 2021$

\section{Introduction}

The interplay between domestic and international law depicts a structural dependence of the latter on the former for its domestic implementation. The domestic legal system must provide a conducive legislative, judicial and administrative framework if treaty-based guarantees are to be translated into reality for domestic beneficiaries. ${ }^{1}$

Moreover, international law recognizes a state to determine the conditions under which international treaties could have effect within its jurisdiction. ${ }^{2}$ In other words, domestic laws and law-making organs have the liberty of choice regarding the manner and means of incorporating ${ }^{3}$ international treaties into 'the law of the land.' This liberty of action, or the margin of discretion, so to speak, is as to how to incorporate ${ }^{4}$ ratified treaties into the domestic legal system but it does not empower local authorities to decide whether to incorporate them at all because the state's duty to incorporate them results from the act of ratification. ${ }^{5}$

On the other hand when it comes to the substantive relationship between international law and domestic law the rules of international law and the practices of international judicial practice dictate the hierarchically higher status of the international norm. ${ }^{6}$ From this it follows that the rank of ratified human rights treaties within states' domestic legal system is determined by international law, not by domestic law.

In Ethiopia the debates on the hierarchical position of human rights treaties ratified by Ethiopia fail to take in account the nature interplay between domestic and international laws discussed in the forgoing paragraphs. The emergent consensus of the dominant literature on the rank of ratified human rights treaties in Ethiopia follows the mistaken approach which allows domestic law to determine the position of treaties at the national level. The aim of the present enquiry is to rebut this mistaken approach and analyze the rank of ratified international human rights treaties in Ethiopia from the international law standpoint.

The article is divided into 5 sections. The next section briefly discusses manner and means of incorporating

\footnotetext{
${ }^{1}$ Carlos Manuel Vazquez, Treaties as Law of the Land: The Supremacy Clause and Presumption of Self-Execution 121 Harvard Law Review $1,14(2008)$

${ }^{2}$ To this effect, for instance, Article 2(2), of the International Civil and Political Covenant provides that a state party to the Covenant is required to implement the rights and freedoms guaranteed in the Covenant in accordance with its 'constitutional process and the Covenant itself. See International Covenant on Civil and Political Rights G.A. Res. 2200A (XXI), U.N. Doc. 2200A (XXI (Dec. 16,1966)[Hereinafter ICCPR], art.2(2)

${ }^{3}$ The word 'incorporate' is used throughout this paper in its non-technical and ordinary sense to refer to the domestication of international treaty provisions in any of the means and methods used by a country

${ }_{4}^{4}$ According to Scheinin, states may opt to employ either or a combination of adoption, incorporation, (active) transformation, passive transformation and reference for purposes of giving effect to a human rights treaties in the domestic law. Regardless of the method of incorporation used, ratified treaties will bind the state and should be given judicial notice by the state's domestic institutions. See Martin Schenin, 'International Human Rights in National Law' in Raija Hanki, and Markku Suksi (ed), An Introduction to the International Protection of Human Rights (2002), p.418-419

${ }^{5}$ Yuval Shany, How Supreme is the Supreme Law of the Land: Comparative Analysis of the Influence of International Human Rights Treaties upon the Interpretation of Constitutional Texts by Domestic Courts', 31 Brooklyn Law Journal 341, 355(2006)

${ }^{6}$ Vazquez, supra note 1 , at 14
} 
human rights treaties into domestic legal systems. Section 3 reviews dominant Ethiopian scholarly position on the rank of ratified human rights treaties in the domestic legal system of Ethiopia. Sanction 4 a presents a rebuttal of the dominant Ethiopian scholarly position on the rank of ratified human rights treaties within Ethiopian domestic legal system from international law standing point. Section 5 concludes the article.

\section{Means of incorporating human rights treaties into domestic legal systems}

As mentioned in the previous section of this article international law recognizes a state to determine the conditions under which international conventions could have effect within its jurisdiction. ${ }^{1}$ Domestic laws and law-making organs have the liberty of choice regarding the manner and means of incorporating ${ }^{2}$ international treaties into 'the law of the land.'

The approach followed by States to domesticate human rights treaties has often been understood by two opposing theories - monism and dualism. ${ }^{4}$ Proponents of these theories consider the application of international law in state territories, or invocability of international law in domestic courts, from the viewpoints of their respective theories, and arrive at diverging conclusions as regards how the treaties would be implemented or enforced by the states. ${ }^{5}$

States labelled as monist do not see any fundamental difference between international law and municipal law. They consider the two as unified field of knowledge, both having normative and legal character, but differing in individual characteristics. Both laws are for human beings, for the human good. ${ }^{6}$ Therefore, monists as a rule accept automatic incorporation of international law, in toto or particular provisions, as a part of the internal legal order, without any need for specific measures to incorporate them. This is usually based on a provision in the constitution of these countries providing for direct applicability and/or direct effect, as the case may be, of international treaties. ${ }^{7}$ Hence, under the monist ideal, international law is automatically incorporated into domestic law when it becomes binding as international law for the state and thus becomes a part of the internal legal order as international law. ${ }^{8}$

In contrast, States labelled as dualists consider international law and domestic law as two separate legal systems, emphasizing that they are created differently, their characteristics are different, their spheres of application and enforcement mechanism are not the same and, therefore, international law cannot be directly applied in state territories, and must conform to specially designed mechanism, i.e., transforming into domestic law first, before international law could be invoked in the domestic court. ${ }^{9}$ In other words, international law is, by a decision of the legislature, made a part of the internal legal order. ${ }^{10}$

When we come to the situation in Ethiopia Article 9(4) the Federal Democratic Republic of Ethiopia[Hereinafter, FDRE ]Constitution provides that all international agreements ratified by Ethiopia are an integral part of the law of the land. ${ }^{11}$ This formulation implies that the provisions of these international instruments are part of the law of Ethiopia. ${ }^{12}$ Consequently, the provisions of such international human rights instruments can be directly applied in national institutions. ${ }^{13}$

The domestication of international human rights instruments is further fortified by article 13(2) of the FDRE Constitution, ${ }^{14}$ which provides that the fundamental rights and freedoms shall be interpreted in a manner conforming to the principles of the Universal Declaration of Human Rights, international covenants on human

\footnotetext{
${ }^{1}$ To this effect, for instance, Article 2(2), of the International Civil and Political Covenant provides that a state party to the Covenant is required to implement the rights and freedoms guaranteed in the Covenant in accordance with its 'constitutional process and the Covenant itself. See, ICCPR, supra note 2, art.2(2)

${ }^{2}$ The word 'incorporate' is used throughout this paper in its non-technical and ordinary sense to refer to the domestication of international treaty provisions in any of the means and methods used by a country

${ }^{3}$ Shany, supra note 5 , at 355 .

${ }^{4}$ J.H. Jackson, Status of Treaties in Domestic Legal Systems: A Policy Analysis, 86 AJIL 313-315 (1992) ; for a very interesting treatment of the issue, see M. Kumm, 'Liberal Constitutional Democracy and the Judicial Enforcement of International Law', paper presented on Globalization and its Discontents at the New York University School of Law on 22 April 2002; Viljoen F International human rights law in Africa $2^{\text {nd }}$ ed (Oxford University Press Oxford 2012)

${ }^{5}$ M.S. Alam , Enforcement of International Human Rights Law By Domestic Courts: A Theoretical And Practical Study, Netherlands International Law Review 399, 404(2006) ${ }^{6} \mathrm{Id}$

${ }^{7}$ Davíd Thór Björgvinsson The Intersection of International Law and Domestic Law (EdwardElgarPublishingLimited Cheltenham 2015), p..1

${ }^{8}$ Id

${ }^{9}$ Alam, supra note 11

${ }^{10}$ See, Kristen Walker and Andrew D. Mitchell, 'A Stronger Role for Customary International Law?' (2005), pp. 125 ff

${ }^{11}$ The Constitution of the Federal Democratic Republic of Ethiopia, Federal Negarit Gazeta, 1st Year, No. 1, 21 August 1995. Hereinafter FDRE Constitution], Art. 9(4). See also, Malcolm N SHAW., International Law (2008) p. 105.

${ }^{12}$ Ethiopia follows the monist tradition where international treaties become an integral part of national law upon ratification. For a discussion on the monist/dualist distinction and the fallacies involved therein, see F. Viljoen supra note 10, at 530-538

${ }^{13}$ C. Tomuscha, National Implementation of International Standards on Human Rights, Can. Hum. Rts. Y.B. 31, 37(1985)

${ }^{14}$ Sisay Alemayehu Yeshanew, The justiciability of human rights in the Federal Democratic Republic of Ethiopia, 8Afr. Hum. Rts. L.J. 273, $285(2008)$
} 
rights and international instruments adopted by Ethiopia. ${ }^{1}$ Consequently, to the extent that the rights protected by the ratified instruments are guaranteed in the FDRE Constitution, the provisions of these treaties would supplement them. ${ }^{2}$

From cumulative reading of articles 9(4) and 13(2) of the FDRE Constitution wen can understand that human rights treaties become part of Ethiopian domestic law as soon as they are ratified. Consequently one can understand that Ethiopia follows the monist tradition where international treaties become an integral part of national law upon ratification. $^{3}$

\section{Rank of incorporated human rights treaties in the domestic legal system of Ethiopia: Emergent consensus of the dominant literature}

A critical appraisal of dominant literature on the rank of human rights treaties under the Constitution of the Federal Democratic Republic of Ethiopia ${ }^{4}$ reveals a converging opinion regarding the normative position of ratified treaties in the country's pyramid of laws. There are two-tiered dimensions to the emerging consensus about the rank of treaties.

First, the supremacy clause of Art 9(1) of the Constitution, rendering any inconsistent 'law, customary practice or a decision of an organ of state or a public official' null and void, has led to the assertion that the Constitution is superior to all ratified treaties. ${ }^{5}$ The fact that the House of Peoples' Representatives (HPR $)^{6}$ is entrusted with treaty ${ }^{7}$ ratifying powers as well as powers to issue proclamations,${ }^{8}$ led to the conclusion that treaties and proclamations of the HPR share parity of status due to their identical formal source. ${ }^{9}$ Accordingly, if, for instance, a provision of a human rights treaty ratified by Ethiopia is inconsistent with the Bill of Rights/ rights which are expressly guaranteed in the FDRE Constitution/, the latter prevails. ${ }^{10}$

Second, going by the requirement of its Art 13 (2) that the Bill of Rights ${ }^{11}$ of the FDRE Constitution must be interpreted in conformity with ratified treaties, one may say that human rights treaties are hierarchically parallel to (or even above) the Constitution. ${ }^{12}$ In such a situation, it may be tenable to argue that Ethiopian domestic laws and the international human rights norms and principles may be regarded as being two parts of a single legal system. And, in the event of a conflict between these two sets of legal regimes, the international law prevails because it serves as guidance. ${ }^{13}$

\section{Rank of incorporated human rights treaties in the domestic legal system of Ethiopia: International law standpoint}

In this section the author presents a rebuttal of emergent consensus of the dominant literature on the status of human rights treaties in Ethiopia which allows domestic law to determine the rank of treaties at the national level.

Accordingly, the author argues that, as opposed to approach followed by dominant literature on the status of human rights treaties in Ethiopia, the rank of ratified human rights treaties in domestic legal systems is determined by the rules of international law. Furthermore, the author argues that such rules of international law dictate the hierarchically higher status of ratified human rights treaties in the domestic legal system of Ethiopia.

The author presents three evidences which reveal the hierarchically higher status of human rights treaties

\footnotetext{
${ }^{1}$ FDRE Constitution, supra note 17, Article 13(2)

${ }^{2}$ Yeshanew, Supra note 20, at 285

${ }^{3}$ For discussion on this point, see Girma Amare, 'The Ethiopian Human Rights Regime, Federal Democratic Republic of Ethiopia's Constitution and International Human Rights Conventions Ethiopia has Ratified.' paper was presented to the International Conference on the Establishment of the Ethiopian Human Rights Commission and the Institution of Ombudsman, from May 18-22, 1998, Addis Ababa, Ethiopia ${ }^{4}$ FDRE Constitution, supra note 17

${ }^{5}$ Chi Mgbako, et al, Silencing the Ethiopian Courts: Non-Judicial Constitutional Review and Its Impact on Human Rights 15 Fordham International Law Journal 701, 713(2008); Sisay Alemahu, The Constitutional Protection of Economic and Social Rights in the Federal Democratic Republic of Ethiopia,' 23 Journal of Ethiopian Law 135, 147( 2008); Gebreamlak Gebregiorgis, 'The Incorporation and Status of International Human Rights under the FDRE Constitution' in Girmachew Alemu and Sisay Alemahu (ed), The Constitutional Protection of Human Rights in Ethiopia: Challenges and Prospects (Ethiopian Human Rights Law Series) (2008) vol 2, 37; Getachew Assefa, 'The Protection of Fundamental Rights and Freedoms in Ethiopian Federalism' (Paper presented at the Proceedings of the First National Conference on Federalism, Conflict and Peace Building, Addis Ababa, 2005) 257; Ibrahim Idris, The Place of International Human Rights Conventions in the 1994 Federal Democratic Republic of Ethiopia (FDRE) Constitution' 20 Journal of Ethiopian Law 113, 132-134(2000); Rakeb Messele, 'Enforcement of Human Rights in Ethiopia' (Action Professionals Association for the People (APAP), 2002) 15

${ }^{6}$ The HPR is the federal parliament with a constitutional mandate of comprehensive 'power of legislation in all matters assigned by this Constitution to Federal jurisdiction.' See FDRE Consitution, supra note 17, Art 55 (1)

${ }^{7}$ In Ethiopia, treaties are concluded (signed) by the State's Executive branch which must subsequently submit it for ratification to the HPR. See FDRE Constitution, supra note 17, art. 55(12)

${ }^{8}$ FDRE Constitution, supra note 17 , Art 55 (1). Proclamations are primary laws that occupy a position second only to the Constitution in the domestic normative hierarchy

${ }^{9}$ Assefa, supra note 25; Idris, supra note 25, at 134; Alemahu, supra note 25;Gebregiorgis, supra note 25 , at 46

${ }^{10}$ Yeshanew , Supra note 20

${ }^{11}$ This refers to Chapter three of the FDRE Constitution running from Art 13-44

${ }^{12}$ Yeshanew, Supra note 20

${ }^{13} \mathrm{Id}$
} 
within the Ethiopian domestic legal system: the nature of obligation entailed by human rights treaties, the principle of pacta sunt servanda, and the principle of consistent interpretation.

\subsection{State's obligations imposed by human rights treaty ratification}

It is by now commonly understood in both international law and in philosophy that human rights treaties impose essential state obligations to respect, protect and fulfill, and ${ }^{1}$ promote. $^{2}$

The obligation to respect requires states "to refrain from interfering directly or indirectly with the enjoyment of" the right in question. ${ }^{3}$ The obligation to protect requires the state to act positively to prevent and remedy the violations of human rights caused by interferences of non-state actors. ${ }^{4}$ The obligation to promote requires the State to undertake the substantial investment involved in expanding knowledge of human rights guarantees and obligations entailed therein. ${ }^{5}$

Obligation to fulfill requires the State to take the measures necessary to ensure for each person within its jurisdiction opportunities to obtain satisfaction of those needs, recognized in the human rights instruments, which cannot be secured by personal efforts. ${ }^{6}$ The States' obligation to fulfill arises when measures taken by States with respect to obligations to respect, protect and promote has not been successful in ensuring enjoyment of human rights. ${ }^{7}$ Hence, it requires the states to take appropriate legislative, administrative, budgetary, judicial and other measures that rights holders need in order to realize and enjoy their rights in full.",

Under the International Covenant on Civil and Political Rights (ICCPR), the most important legal basis for the four kinds of state obligations entailed by human rights is Article 2(1) which requires each state party "to respect and to ensure to all individuals within its territory and subject to its jurisdiction the rights recognized in the present Covenant." Although the ICESCR does not include the "respect and ensure" language, the Committee on Economic, Social and Cultural Rights has read it to require parties to protect rights, as well as to respect and fulfill them. ${ }^{10}$ At regional level, although Article 1 of the African Charter requires its parties only to "recognize" its listed rights and to undertake to adopt legislative or other measures to give effect to them, the African Commission has read it to require parties to respect, protect, promote, and fulfill rights. ${ }^{11}$

The quartet layers of state obligations discussed above are analytic tools for gauging whether and to what extent a state has been implementing or violating a given human right, while they also reflect the manner in which the state must behave in order to discharge its human rights obligations. ${ }^{12}$

\subsection{The principle of pacta sunt servanda}

With respect to obligations arising from international law, the principle of pacta sunt servanda dictates that treaties willfully entered into should be executed in good faith. Indubitably, the principle of pacta sunt servanda in the law of treaties is based on good faith, ${ }^{13}$ ' and the maxim has constituted 'since time immemorial the axiom, postulate and categorical imperative of the science of international law. ${ }^{14}$

${ }^{1}$ H. Shue Basic Rights. Subsistence, Affluence and U.S. Foreign Policy 2nd ed (Princeton University Press 1996). a similar typology was developed contemporaneously by A. Eide, ultimately adopted by the United Nations in A. Eide (UN Special Rapporteur on the Right to Food), The Right to Food (Final Report) UN.Doc. E/CN.4/Sub.2/1987/23 (1987), paras. 66-69.

${ }^{2}$ Communication 155/96, The Social and Economic Rights Action Center and the Center for Economic and Social Rights vs Nigeria, 15 th Annual Activity Report, Para 44, (hereinafter 'SERAC'case)

${ }^{3}$ ESCR Committee, General Comment No. 14, The Right to the Highest Attainable Standard of Health, P 33, U.N. Doc. E/C.12/2000/4 (Nov. 8, 2000), available at http://www.ohchr.org/english/bodies/cescr/comments.htm, P 33.

${ }^{4}$ See Daphne Barak-Erez, and Aeyal M Gross, 'Introduction: Do We Need Social Rights? Questions in the Era of Globalisation, Privatisation, and the Diminished Welfare State' in Aeyal M Gross and Daphne Barak-Erez (ed), Exploring Social Rights: Between Theory and Practice (2007) 3, 7-8; Aeyal M Gross, 'The Right to Health in an Era of Privatisation and Globalisation: National and International Perspectives' in Daphne Barak-Erez and Aeyal M Gross (ed), Exploring Social Rights: Between Theory and Practice (2007) 289, 303; SERAC supra note 35, Para 46.

${ }^{5}$ N.J. Udombana, Between Promise and Performance: Revisiting States' Obligations Under the African Human Rights Charter, (40) Stan. J. Int'1 L. 105, 134(2004)

${ }^{6}$ A. Eide, Realization of Social and Economic Rights and the Minimum Threshold Approach,10Human Rights Law Journal 35, 37 (1989);

S.H. Cleveland, embedded international law and the constitution abroad 110 Colum. L. Rev.225, 283 (2010

${ }^{7}$ Mesenber Assefa, defining the minimum core obligations-conundrums in international human rights law and lessons from the constitutional court of South Africa' Mekelle U. L.J.48, 51 (xxx); SERAC case, supra note 35, para. 47

${ }^{8}$ W. Kalin and J. Kunzli The Law of International Human Rights Protection (Oxford University Press Oxford 2009), p.112; Shue , supra note 34, at 160; The Maastricht Guidelines on Violations of Economic, Social and Cultural Rights 20 HuM. RTS. Q 693-94, para 6 (1998) ; SERAC case, supra note 35 , para. 47

${ }^{9}$ ICCPR, supra note 2, Art. 2(1). See also, Hum. Rts. Comm., General Comment No. 31, UN Doc. CCPR/C/21/Rev. 1/Add. 13, para. 8 (May 26,2004)

${ }^{10}$ Committee on Economic, Social and Cultural Rights, General Comment No. 12, UN Doc. E/C. 12/1999/5, para. 15 (May 12, 1999) (right to food); \& General Comment No. 14, UN Doc. E/C.12/2000/4, para. 33 (right to health)

${ }^{11}$ SERAC case, supra note 35 , Para 44

${ }^{12}$ Magdalena Sepulveda, The Nature of the Obligations under the International Covenant on Economic, Social, and Cultural Rights (2003) 172

${ }^{13}$ Under Art 26 of the VCLT, 'Every treaty in force is binding upon the parties to it and must be performed by them in good faith. See, Vienna

Convention on the Law of Treaties art. 53, May 23, 1969, 1155 U.N.T.S 331 (entered into force Jan. 27, 1980), [Hereinafter VCLT]

${ }^{14}$ J F O'Connor, Good Faith in English Law (1990), p.5-10 
The principle of good faith requires states to maintain domestically such laws and institutions as will enable them to discharge their international obligations. This has been codified under the VCLT, which provides that:

A State is obliged to refrain from acts which would defeat the object and purpose of a treaty when... (b) it has expressed its consent to be bound by the treaty. ${ }^{1}$

According to Bradley, this provision reflects customary international law, the rules and principles of which are binding on all nations irrespective of consent, including those states that have yet to ratify the VCLT. ${ }^{2}$ More specifically, Brownlie asserted that the law and jurisprudence in this area is nothing but 'settled':

A state cannot plead provisions of its own law or deficiencies in that law inanswer to a claim against it for an alleged breach of its obligations under international law. The acts of the legislature and other sources of internal rules and decision-making are not tobe regarded as acts of third party for which the state is not responsible, and any other principle would facilitate evasion of obligations. ${ }^{3}$

The upshot of the above discussion is that international law complements supplements and overrides contrary domestic law in matters involving the protection of human and peoples' rights. There is a need to bring domestic legislation, administrative rules and practices into conformity ${ }^{4}$ with the international treaties which are 'high minded-legal formulations.' 5

\subsection{The principle of consistent interpretation}

The principle of consistent interpretation is sometimes referred to as the 'Charming Betsy' doctrine. Put in simple terms, the principle means that a national statute must be construed so as not to conflict with international law. ${ }^{6}$

There are different grounds or reasons for applying consistent interpretation. First, International law in a certain field may dictate that contracting states are under the obligation to interpret national law as consistent with the state's obligations. This is well known, for example, in EU law as well as EEA law. ${ }^{7}$

However, one may rightly ask the question whether states are under a general obligation to apply a consistent interpretation. ${ }^{8}$ Nollkaemper suggests that it is possible to infer such an obligation from state practice, 'in combination with the general principle of effective treaty interpretation, a general principle of interpretation such that, within the limits of their domestic powers, national courts should interpret domestic law in conformity with the international obligations of the state.' 9

The second element is legislative intent. Legislative intent is an accepted canon of interpretation in most legal systems. Related to this canon of interpretation is the presumption that the legislature did not intend to legislate in breach of an international legal obligation. This rule of presumption is a part of the principle of consistent interpretation, but only a part. It is possible to distinguish two different versions of the rule of presumption.

The narrower version is confined to incorporated treaties. The fact that the legislature has decided to incorporate a treaty gives rise to the presumption that the legislature intended to make domestic law conform to a treaty. Domestic law should therefore be interpreted in line with the underlying international obligation. ${ }^{10}$

The broader version is not limited to the implementing legislation, but relates to any laws adopted after a particular international obligation entered into force. In this situation the presumption is that the legislature did not intend to legislate contrary to international obligations. It follows that the legislation must be interpreted to conform to an existing treaty. ${ }^{11}$

It is to be noted that this broader version of the presumed intent of the legislature does not easily accommodate domestic legislation already in force when a particular international obligation came into force. ${ }^{12}$ But this is not always so, since in literature it is argued that the rule of presumption, as it is called, applies also to national law provisions older than the relevant international obligation. The rationale is that the legislature did not intend to keep in force an existing national provision which is contrary to or incompatible with the international obligations of the state. ${ }^{13}$

\footnotetext{
${ }^{1}$ VCLT , supra note 46 , Art 18

${ }^{3}$ Ian Brownlie, Principles of Public International Law (2008), p. 34 Rights (African Charter) 1986, OAU Doc. CAB/LEG/67/Rev.5, (Art 1) (1997) 24. 240. See also Bauden- Bacher, Carl, 'Methods of Interpretation' (2010), pp. 30-46.

${ }^{8}$ David Feldman, 'Monism, Dualism and Constitutional Legitimacy' (1999), p. 106

${ }^{9}$ André Noll-kaemper, National Courts and the International Rule of Law (2011), p. 149

${ }^{10}$ Björgvinsson, supra note 13 , at $\mathrm{p}$.

${ }^{11}$ Id

${ }^{12}$ Noll-kaemper, supra note 56, at $154-155$

${ }^{13}$ Ole Spiermann (2004)160-61
}

${ }^{2}$ Curtis A Bradley, Unratified Treaties, Domestic Politics, and the U.S. Constitution, 48 Harvard International Law Journal 307, 307(2007)

${ }^{4}$ This is part of the domestic implementation of ratified treaties, which specifically require the state parties to take, inter alia, legislative measures to ensure their domestic applicability. Just to cite examples: ICCPR, supra note 7, Art 2(2) ; African Charter of Human and Peoples'

${ }^{5}$ Philip Alston, 'The Purposes of Reporting' ' in Manual on Human Rights Reporting Under Six Major International Human Rights Instruments

${ }^{6}$ See Murray v. The Charming Betsy, 6 U.S. (2 Cranch) 64 (1804), where the following is stated: 'It has also been observed that an act of Congress ought never to be construed to violate the law of nations if any other possible construction remains ....' ${ }^{7}$ See Case E-4/01 - Karl K. Karlsson hf. V The Icelandic State. Judgment 30 May 2002 (para. 28) EFTA Ct. Rep. 2002, p. 
In sum, from the above discussion we can conclude that principle of consistent interpretation which requires that a national statute must be construed in conformity with international law implies that that human rights treaties ratified by Ethiopia are hierarchically above other Ethiopia's domestic laws because these treaties serves as guidance.

\section{Conclusion}

The interplay between domestic and international law depicts a dependence of the latter on the former for its implementation. The domestic legal system must provide a conducive legislative, judicial and administrative framework if treaty-based guarantees are to be translated into reality for domestic beneficiaries. ${ }^{1}$ On the other hand, international law recognizes a state to determine the conditions under which international conventions could have effect within its jurisdiction. Domestic laws and law-making organs have the liberty of choice regarding the manner and means of incorporating international treaties into 'the law of the land. ${ }^{2}$

When it comes to the substantive relationship international law and domestic law the rules of international law and the practices of international judicial practice dictate the hierarchically higher status of the international norm. ${ }^{3}$ Therefore, rank of ratified human rights treaties within domestic legal system is determined by international law, not by domestic law.

This article has indicated that the debate on the hierarchical position of ratified human rights treaties fails to take in account the nature interplay between domestic and international laws. The emergent consensus of the dominant literature on the status of human rights treaties in Ethiopia follows the mistaken approach which allows domestic law to determine the position of treaties at the national level.

This article has presented three evidences for the hierarchically higher status of human rights treaties within the Ethiopian domestic legal system: the nature of obligation entailed by human rights treaties, the principle of pacta sunt servanda, and the principle of consistent interpretation.

Human rights treaties impose essential obligations to respect, protect and fulfill, and ${ }^{4}$ promote $^{5}$. The principle of pacta sunt servanda stipulates that a state cannot plead provisions of its own law or deficiencies in that law in answer to a claim against it for an alleged breach of its obligations under international law. ${ }^{6}$ The principle of consistent interpretation which is sometimes referred to as the 'Charming Betsy' doctrine means that a national statute must be construed so as not to conflict with international law. ${ }^{7}$

In sum, once human rights treaties are domesticated they apply irrespective of contradictory domestic laws and practices. In other words, human rights treaties remain binding on the country, and a law, conduct or decision that deviates from the treaty requirements can only be found in the realm of treaty violation. Treaties thus occupy a position superior to that of Ethiopian constitution and other laws, which, if inconsistent with ratified treaties, should give way to the domestic application of treaty-based remedies.

\section{References}

Books

André Noll-kaemper National Courts and the International Rule of Law (2011)

Calr Bauden- Bacher Methods of Interpretation (2010)

Davíd Thór Björgvinsson The Intersection of International Law and Domestic Law (EdwardElgarPublishingLimited Cheltenham 2015)

David Feldman Monism, Dualism and Constitutional Legitimacy (1999)

F Viljoen International human rights law in Africa $2^{\text {nd }}$ ed (Oxford University Press Oxford 2012)

H. Shue Basic Rights. Subsistence, Affluence and U.S. Foreign Policy 2nd ed (Princeton University Press 1996) Ian Brownlie, Principles of Public International Law (2008)

J F O'Connor Good Faith in English Law (1990)

Kristen Walker and Andrew D. Mitchell, A Stronger Role for Customary International Law? (2005)

Malcolm N SHAW International Law (2008)

Magdalena Sepulveda The Nature of the Obligations under the International Covenant on Economic, Social, and Cultural Rights (2003)

Rakeb Messele Enforcement of Human Rights in Ethiopia (Action Professionals Association for the People (APAP), 2002)

W. Kalin and J. Kunzli The Law of International Human Rights Protection (Oxford University Press Oxford 2009)

\footnotetext{
${ }^{1}$ Vazquez, supra note 1 , at 14

${ }^{2}$ Shany, supra note 5 , at 355.

${ }^{3}$ Vazquez, supra note 1 , at 14

${ }^{4}$ Shue, supra note 34

${ }^{5}$ SERAC case, supra note 35

${ }^{6}$ Ian Brownlie, supra note 50

${ }^{7}$ See Murray v. The Charming Betsy, 6 U.S. (2 Cranch) 64 (1804)
} 


\section{Book chapters}

Aeyal M Gross, 'The Right to Health in an Era of Privatisation and Globalisation: National and International Perspectives' in Daphne Barak-Erez and Aeyal M Gross (ed), Exploring Social Rights: Between Theory and Practice (2007)

Daphne Barak-Erez, and Aeyal M Gross, 'Introduction: Do We Need Social Rights? Questions in the Era of Globalisation, Privatisation, and the Diminished Welfare State' in Aeyal M Gross and Daphne Barak-Erez (ed), Exploring Social Rights: Between Theory and Practice (2007)

Gebreamlak Gebregiorgis, 'The Incorporation and Status of International Human Rights under the FDRE Constitution' in Girmachew Alemu and Sisay Alemahu (ed), The Constitutional Protection of Human Rights in Ethiopia: Challenges and Prospects (Ethiopian Human Rights Law Series) (2008) vol 2

Martin Schenin, 'International Human Rights in National Law' in Raija Hanki, and Markku Suksi (ed), An Introduction to the International Protection of Human Rights (2002)

Philip Alston, 'The Purposes of Reporting' ' in Manual on Human Rights Reporting Under Six Major International Human Rights Instruments (1997)

\section{Journal articles}

A. Eide, Realization of Social and Economic Rights and the Minimum Threshold Approach,10Human Rights Law Journal 35 (1989)

Curtis A Bradley, Unratified Treaties, Domestic Politics, and the U.S. Constitution, 48 Harvard International Law Journal 307(2007)

C. Tomuscha, National Implementation of International Standards on Human Rights, Can. Hum. Rts. Y.B. 31(1985)

Carlos Manuel Vazquez, Treaties as Law of the Land: The Supremacy Clause and Presumption of Self-Execution 121 Harvard Law Review 1(2008)

Chi Mgbako, et al, Silencing the Ethiopian Courts: Non-Judicial Constitutional Review and Its Impact on Human Rights 15 Fordham International Law Journal 701(2008)

Ibrahim Idris, The Place of International Human Rights Conventions in the 1994 Federal Democratic Republic of Ethiopia (FDRE) Constitution' 20 Journal of Ethiopian Law 113, 132(2000)

J.H. Jackson, Status of Treaties in Domestic Legal Systems: A Policy Analysis, 86 AJIL 313(1992)

Mesenber Assefa, defining the minimum core obligations-conundrums in international human rights law and lessons from the constitutional court of South Africa' Mekelle U. L.J.48, 51 (xxx)

M.S. Alam, Enforcement of International Human Rights Law By Domestic Courts: A Theoretical And Practical Study, Netherlands International Law Review 399(2006)

N.J. Udombana , Between Promise and Performance: Revisiting States' Obligations Under the African Human Rights Charter, (40) Stan. J. Int'1 L. 105(2004)

Sisay Alemahu, The Constitutional Protection of Economic and Social Rights in the Federal Democratic Republic of Ethiopia,' 23 Journal of Ethiopian Law 135( 2008)

Sisay Alemayehu Yeshanew, The justiciability of human rights in the Federal Democratic Republic of Ethiopia, 8Afr. Hum. Rts. L.J. 273 (2008)

S.H. Cleveland, embedded international law and the constitution abroad 110 Colum. L. Rev.225 (2010

Yuval Shany, How Supreme is the Supreme Law of the Land: Comparative Analysis of the Influence of International Human Rights Treaties upon the Interpretation of Constitutional Texts by Domestic Courts', 31 Brooklyn Law Journal 341, 355(2006)

\section{International and regional instruments}

African Charter of Human and Peoples' Rights (African Charter) 1986, OAU Doc. CAB/LEG/67/Rev.5

A. Eide (UN Special Rapporteur on the Right to Food), The Right to Food (Final Report) UN.Doc. E/CN.4/Sub.2/1987/23 (1987)

Committee on Economic, Social and Cultural Rights, General Comment No. 12, UN Doc. E/C. 12/1999/5, para. 15 (May 12, 1999) (right to food); \& General Comment No. 14, UN Doc. E/C.12/2000/4, para. 33 (right to health)

Communication 155/96, The Social and Economic Rights Action Center and the Center for Economic and Social Rights vs Nigeria, 15 th Annual Activity Report

ESCR Committee, General Comment No. 14, The Right to the Highest Attainable Standard of Health, P 33, U.N. Doc. E/C.12/2000/4 (Nov. 8, 2000), available at http:/www.ohchr.org/english/bodies/cescr/comments.htm

Hum. Rts. Comm., General Comment No. 31, UN Doc. CCPR/C/21/Rev. 1/Add. 13, para. 8 (May 26,2004)

International Covenant on Civil and Political Rights G.A. Res. 2200A (XXI), U.N. Doc. 2200A (XXI (Dec. 16,1966)

Vienna Convention on the Law of Treaties art. 53, May 23, 1969, 1155 U.N.T.S 331 (entered into force Jan. 27, 
1980)

The Maastricht Guidelines on Violations of Economic, Social and Cultural Rights 20 HuM. RTS. Q 693-94, para $6(1998)$

\section{Conference/Seminar papers}

Girma Amare, 'The Ethiopian Human Rights Regime, Federal Democratic Republic of Ethiopia's Constitution and International Human Rights Conventions Ethiopia has Ratified.' paper was presented to the International Conference on the Establishment of the Ethiopian Human Rights Commission and the Institution of Ombudsman, from May 18-22, 1998, Addis Ababa, Ethiopia

Getachew Assefa, 'The Protection of Fundamental Rights and Freedoms in Ethiopian Federalism' (Paper presented at the Proceedings of the First National Conference on Federalism, Conflict and Peace Building, Addis Ababa, 2005)

M. Kumm, 'Liberal Constitutional Democracy and the Judicial Enforcement of International Law', paper presented on Globalization and its Discontents at the New York University School of Law on 22 April 2002

\section{Cases}

Case E-4/01 - Karl K. Karlsson hf. V The Icelandic State. Judgment 30 May 2002 (para. 28) EFTA Ct. Rep. 2002 Murray v. The Charming Betsy, 6 U.S. (2 Cranch) 64 (1804)

Murray v. The Charming Betsy, 6 U.S. (2 Cranch) 64 (1804)

\section{Ethiopian laws}

Proclamation No. 4/1995, A Proclamation to Provide For the Definition of Powers and Duties of the Executive Organs of the Federal Democratic Republic Of Ethiopia, Federal Negarit Gazeta, 1st Year, No.4, 23 August 1995.

The Constitution of the Federal Democratic Republic of Ethiopia, Federal Negarit Gazeta, 1st Year, No. 1, 21 August 1995 